\title{
ANALISIS KADAR KLORIN PADA TEH CELUP BERDASARKAN WAKTU SEDUHAN
}

\author{
S. Wansi ${ }^{1}$, Syahran Wael ${ }^{2}$ \\ ${ }^{1}$ Alumni Progam Studi Pendidikan Biologi \\ ${ }^{2}$ Dosen Program Studi Pendidikan Biologi
}

E-mail: wansibio@yahoo.com

\begin{abstract}
Abstact
Background: Tea is the most widely consumed beverages by all levels of society because in addition to economical, tea is also thought to provide health benefits. Compounds that contribute to the health of the body such as tannins, catechins, flavanols and cafein. Along with its development era community prefers tea bag as it is easy and practical use. Without realizing it, the longer the brewed tea bag in the water substance called chlorine bleach paper contained in tea bags rather the bag of tea bags will also be dissolved.

Method: This research includes the study of laboratory experiments. Object in this study is 4 (four) brand of tea bag and then examined in a Laboratory Ambon Pattimura University Biology Education using thiosulfate titration methode.

Result: Anova and Tukey test results indicate that there are differences in the levels of chlorine-based treatment duration and type of tea steeping. The study test showed was obtained at the highest levels of chlorine treatment A1P4 (0,413 ppm) and A4P1 treatment resulted in the lowest levels of chlorine $(0,058 \mathrm{ppm})$.

Conclusion: There are differences in the levels of chlorine in various brands of tea bag is Sariwangi tea, sosro tea, poci tea and tong tji tea for time 2 minutes, 4 minutes, 6 minutes and 8 minutes.
\end{abstract}

Keyword: Keywords: Tea bags, Steeping time and Chlorine

\begin{abstract}
Abstrak
Latar Belakang: Teh merupakan minuman yang paling banyak dikonsumsi oleh semua lapisan masyarakat karena selain ekonomis, teh juga dianggap dapat memberikan manfaat bagi kesehatan. Senyawa-senyawa yang berperan bagi kesehatan tubuh antara lain tanin, katekin, flavanol dan kafein. Seiring dengan berkembangnya jaman maka masyarakat lebih memilih teh celup karena mudah dan praktis penggunaannya. Tanpa disadari, semakin lama teh celup diseduh dalam air maka zat pemutih kertas yang disebut klorin yang terdapat pada teh celup tepatnya pada kantong teh celup juga akan terlarut.

Metode: Penelitian ini termasuk dalam penelitian eksperimen laboratorium. Objek dalam penelitian ini adalah 4 (empat) merek teh celup dan kemudian diperiksa di Laboratorium Pendidikan Biologi Universitas Pattimura Ambon dengan menggunakan metode titrasi thiosulfat.

Hasil: Hasil uji Anova dan uji Tukey menunjukkan bahwa terdapat perbedaan kadar klorin berdasarkan perlakuan lama waktu seduhan dan jenis teh. Hasil penelitian menunjukkan bahwa kadar klorin tertinggi diperoleh pada perlakuan A1P4 $(0,413 \mathrm{ppm})$ dan perlakuan A4P1 menghasilkan kadar klorin paling rendah $(0,058 \mathrm{ppm})$.

Kesimpulan: Terdapat perbedaan kadar klorin pada berbagai merek teh celup yaitu teh celup Sariwangi, teh celup Sosro, teh celup Poci dan teh celup Tong Tji berdasakan lama waktu seduhan 2 menit, 4 menit, 6 menit dan 8 menit.
\end{abstract}

Kata Kunci: Teh celup, Waktu seduhan dan Klorin 


\section{PENDAHULUAN}

Teh merupakan salah satu jenis tanaman yang tumbuh subur di tanah air kita, terutama di daerah-daerah yang berhawa dingin. Pada umumnya masyarakat kita terbiasa minum teh dalam kehidupan kesehariannya. Selama ini teh yang kita minum berasal dari daun teh (Semeru, 1995). Teh merupakan minuman yang paling banyak dikonsumsi oleh semua lapisan masyarakat karena selain ekonomis, teh juga dianggap dapat memberikan manfaat bagi kesehatan. Senyawa-senyawa yang berperan bagi kesehatan tubuh antara lain tanin, katekin, flavanol dan kafein. Akan tetapi, seiring dengan berkembangnya jaman maka masyarakat lebih memilih sesuatu yang mudah dan praktis begitu pula dengan pola konsumsi teh. Aneka produk olahan dari bahan baku teh banyak dijumpai di pasaran dalam bentuk yang siap minum seperti teh kotak, teh botol dan lain-lain. Di antara produk tersebut, teh celup merupakan suatu produk yang sudah dikenal dan sangat digemari oleh masyarakat karena sangat praktis penggunaannya (Suryaningrum, $d k k, 2007$ ).

Produk teh celup yang paling populer di masyarakat yaitu teh celup sariwangi dan teh celup sosro. Kedua teh celup ini merupakan merek teh lokal terkemuka yang secara eksklusif beroperasi dalam segmen teh celup dengan suatu cara moderen untuk minum teh yang lain dari teh bubuk. Selain kedua teh celup tersebut ada juga merek teh celup lain yang lumayan populer seperti teh celup poci, teh celup tong tji dan teh celup walini (Bambang, 2010).

Menurut Sari (2003), konsumen lebih menyukai teh celup dari pada teh seduh karena membutuhkan waktu lama untuk menyeduhnya. Teh celup merupakan bubuk teh yang dibungkus kertas berpori-pori halus dan tahan panas. Penggunaan teh celup sangat mudah karena konsumen hanya tinggal mencelupkan teh yang telah dikemas tersebut ke dalam air panas sampai warna air berubah. Selain itu, seringkali konsumen berlama-lama mencelupkan teh celupnya ke dalam air panas dengan asumsi bahwa semakin lama kantong teh celup dicelupkan dalam air panas maka semakin banyak khasiat teh tertinggal dalam minuman. Tetapi tidak demikian karena menurut Fulder (2004), waktu penyeduhan yang lebih lama
(4-8 menit) tidak lagi memiliki efek menenangkan karena daun teh sudah tidak lagi mengandung komposisi seperti kafein yang dianggap menenangkan. Tetapi yang harus diwaspadai dari penggunaan teh celup adalah adanya bahan kimia dalam kantong teh celup. Zat pemutih kertas yang disebut klorin yang terdapat pada teh celup tepatnya pada kantong teh celup juga akan terlarut.

Dampak dari teh celup yang mengandung klorin untuk kesehatan baru akan muncul 15 hingga 20 tahun mendatang, khususnya bila kita mengonsumsi teh celup dengan lama waktu seduhan yang salah secara terus menerus. Gangguan kesehatan yang dapat ditimbulkan akibat mengonsumsi teh celup yang mengandung klorin dalam jangka panjang menyebabkan penyakit pada paruparu seperti pneumonitis, sesak nafas, emphisema dan bronkitis (Tirthawidhi, 2011).

Berdasarkan fakta bahwa adanya zat klorin yang terkandung dalam teh celup tepatnya pada kantong teh celup dan bahayanya terhadap kesehatan masyarakat maka penulis tertarik melakukan penelitian ini. Penelitian ini bertujuan untuk mengetahui perbedaan kadar klorin berdasarkan lama waktu seduhan dan jenis teh celup serta untuk mengetahui interaksi antara lama waktu seduhan dan jenis teh celup. Penelitian ini termasuk dalam penelitian eksperimen laboratorium.

\section{MATERI DAN METODE}

Alat dan Bahan yang digunakan dalam penelitian ini yaitu panci, kompor, beaker glass, termometer, jam atau stop watch, gelas ukur, erlenmeyer, mikro buret, timbangan analitik, batang pengaduk, pinset, teh celup, aquadest, $\mathrm{Na}_{2} \mathrm{~S}_{2} \mathrm{O}_{3}, \mathrm{CH}_{3} \mathrm{COOH}, \mathrm{KI}$ dan indikator kanji atau amilum.

Prosedur penelitian dimulai dengan menyeduh teh celup yaitu pertama air dimasukkan ke dalam panci dan direbus dengan menggunakan kompor. Kemudian air rebus diukur sebanyak $\pm 250 \mathrm{ml}$ dengan menggunakan gelas ukur. Setelah itu, air tersebut dituangkan ke dalam beaker glass sambil memasukkan termometer kedalamnya dan menunggu hingga suhu air turun sampai $80^{\circ} \mathrm{C}$. Kemudian teh celup dimasukkan pada air tersebut dan diseduh 
masing-masing selama 2 menit, 4 menit, 6 menit dan 8 menit. Kemudian teh celup tersebut diangkat dengan pinset.

Setelah itu dilanjutkan dengan prosedur penelitian untuk kadar klorinnya dengan metode titrasi thiosulfat yaitu pertama mengambil volume sampel (seduhan teh celup) sebanyak $200 \mathrm{ml}$ dengan gelas ukur dan dimasukkan ke dalam erlenmeyer. Tuangkan $5 \mathrm{ml} \mathrm{CH}{ }_{3} \mathrm{COOH}$ ke dalam sampel. Tambahkan $\pm 1 \mathrm{~g} \mathrm{KI}$ dan mengaduknya terus. Menitrasi sampel dengan $\mathrm{Na}_{2} \mathrm{~S}_{2} \mathrm{O}_{3}$ $0,010 \mathrm{~N}$ dengan mikroburet hingga warna kuning akan tampak. Tambahkan $2 \mathrm{ml}$ kanji atau amilum sehingga sampel akan tampak berwarna biru, Kemudian menitrasi sampel dengan $\mathrm{Na}_{2} \mathrm{~S}_{2} \mathrm{O}_{3}$ 0,010 N dengan mikroburet sampai warna biru hilang pada titik akhir titrasi. Cara menghitung kadar klorin dengan rumus:

$$
\text { Kadar Klorin }=\frac{(A \times B) \cdot N .35,45 \times 1000}{V}
$$

Dimana:

A : Titran $\mathrm{Na}_{2} \mathrm{~S}_{2} \mathrm{O}_{3}$ untuk sampel $(\mathrm{mL})$

$B$ : Titran $\mathrm{Na}_{2} \mathrm{~S}_{2} \mathrm{O}_{3}$ untuk blangko sampel $(\mathrm{mL})$

$\mathrm{N}$ : Normalitas larutan titran $\mathrm{Na}_{2} \mathrm{~S}_{2} \mathrm{O}_{3}(\mathrm{~N})$

$\mathrm{V}$ : Volume sampel $(\mathrm{mL})$

Data dalam penelitian ini diperoleh dengan cara observasi dan kepustakaan serta dianalisis dengan program SPSS versi 16 dengan uji parametrik menggunakan analisis Varians dan dilanjutkan dengan menggunakan uji Tukey.

\section{HASIL DAN PEMBAHASAN Hasil Penelitian}

Berdasarkan hasil penelitian analisis kadar klorin pada merek teh celup berdasarkan waktu seduhan yang dilakukan pada Laboratorium menunjukkan bahwa setiap teh celup memiliki kadar klorin yang berbeda pada setiap merek dan waktu seduhan. Hasil penelitian yang diperoleh dapat dilihat pada tabel 1 di bawah ini. 
Biopendix, Volume 1, Nomor 1, Oktober 2014, hlm. 22-31

Tabel 1. Data Hasil Penelitian Kadar Klorin Pada Teh Celup (ppm).

\begin{tabular}{|c|c|c|c|c|c|}
\hline \multirow{2}{*}{ Perlakuan } & \multicolumn{3}{|c|}{ Ulangan } & \multirow{2}{*}{ Total } & \multirow{2}{*}{ Rata-Rata } \\
\hline & U1 & U2 & U3 & & \\
\hline A1P1 & 0,132 & 0,177 & 0,088 & 0,397 & 0,132 \\
\hline A1P2 & 0,265 & 0,221 & 0,177 & 0,663 & 0,221 \\
\hline A1P3 & 0,354 & 0,398 & 0,265 & 1,017 & 0,339 \\
\hline A1P4 & 0,443 & 0,443 & 0,354 & 1,24 & 0,413 \\
\hline $\mathrm{A} 2 \mathrm{P} 1$ & 0,088 & 0,132 & 0,088 & 0,308 & 0,102 \\
\hline A2P2 & 0,132 & 0,177 & 0,132 & 0,441 & 0,147 \\
\hline A2P3 & 0,265 & 0,221 & 0,221 & 0,707 & 0,235 \\
\hline $\mathrm{A} 2 \mathrm{P} 4$ & 0,398 & 0,354 & 0,310 & 1,062 & 0,354 \\
\hline A3P1 & 0,044 & 0,088 & 0,088 & 0,22 & 0,073 \\
\hline A3P2 & 0,088 & 0,132 & 0,177 & 0,397 & 0,132 \\
\hline A3P3 & 0,177 & 0,177 & 0,221 & 0,575 & 0,191 \\
\hline A3P4 & 0,265 & 0,265 & 0,310 & 0,84 & 0,28 \\
\hline A4P1 & 0,088 & 0,044 & 0,044 & 0,176 & 0,058 \\
\hline A4P2 & 0,132 & 0,088 & 0,132 & 0,352 & 0,117 \\
\hline A4P3 & 0,177 & 0,132 & 0,177 & 0,486 & 0,162 \\
\hline A4P4 & 0,221 & 0,265 & 0,265 & 0,751 & 0,250 \\
\hline
\end{tabular}

Data Hasil Penelitian April 2014

Ket : $\mathrm{A} 1=$ Teh celup sariwangi

$\mathrm{P} 1$ = Lama seduhan 2 menit

$\mathrm{A} 2=$ Teh celup sosro

P2 = Lama seduhan 4 menit

A3 $=$ Teh celup poci

P3 = Lama seduhan 6 menit

A4 $=$ Teh celup tong tji

P4 = Lama seduhan 8 menit

Tabel di atas terlihat bahwa kadar klorin dengan lama seduhan 2 menit pada merek teh sariwangi adalah $0.132 \mathrm{ppm}$ lebih besar dari merek sosro $0.102 \mathrm{ppm}$ merek poci 0.073 ppm, dan merek tongtji 0.058 ppm.
Tetapi lebih sedikit adalah pada merek tongtji yaitu $0.058 \mathrm{ppm}$.

Hasil analisis klorin pada merek teh yang berbeda dengan waktu seduhan yang berbeda juga terdapat nilai yang berbeda dapat dilihat pada tabel 2 berikut ini. 
Tabel 4.2. Hasil Analisis Kadar Klorin Pada Teh Celup dari Berbagai Lama Waktu Seduhan.

\begin{tabular}{|c|c|c|c|c|c|}
\hline Merek teh & $\begin{array}{c}\text { Waktu } \\
\text { seduhan }\end{array}$ & Mean & Minimum & Maksimum & $\begin{array}{c}\text { Std } \\
\text { deviation }\end{array}$ \\
\hline \multirow[t]{4}{*}{ Sariwangi } & 2 menit & 0.132 & 0.088 & 0.177 & 0.044 \\
\hline & 4 menit & 0.221 & 0.177 & 0.265 & 0.044 \\
\hline & 6 menit & 0.339 & 0.265 & 0.398 & 0.067 \\
\hline & 8 menit & 0.413 & 0.354 & 0.443 & 0.051 \\
\hline \multirow[t]{4}{*}{ Sosro } & 2 menit & 0.102 & 0.088 & 0.132 & 0.025 \\
\hline & 4 menit & 0.147 & 0.132 & 0.177 & 0.025 \\
\hline & 6 menit & 0.235 & 0.221 & 0.265 & 0.025 \\
\hline & 8 menit & 0.354 & 0.310 & 0.398 & 0.044 \\
\hline \multirow[t]{4}{*}{ Poci } & 2 menit & 0.073 & 0.044 & 0.088 & 0.044 \\
\hline & 4 menit & 0.132 & 0.088 & 0.177 & 0.025 \\
\hline & 6 menit & 0.191 & 0.177 & 0.221 & 0.044 \\
\hline & 8 menit & 0.280 & 0.265 & 0.310 & 0.025 \\
\hline \multirow[t]{4}{*}{ Tong tji } & 2 menit & 0.058 & 0.044 & 0.088 & 0.025 \\
\hline & 4 menit & 0.117 & 0.088 & 0.132 & 0.025 \\
\hline & 6 menit & 0.162 & 0.132 & 0.177 & 0.025 \\
\hline & 8 menit & 0.250 & 0.221 & 0.265 & 0.025 \\
\hline
\end{tabular}

Dari tabel di atas dapat dilihat bahwa nilai rata-rata tertinggi terdapat pada lama waktu seduhan 8 menit pada merek teh celup sariwangi adalah 0.413 yang mana lebih besar dari pada nilai rata-rata merek teh celup sosro 0.354 , teh celup poci 0.280 dan teh celup tong tji 0.250 . Nilai minimum terdapat pada lama waktu seduhan 2 menit pada merek teh celup tong tji yaitu 0.044 , sedangkan nilai maksimum terdapat pada lama waktu seduhan 8 menit pada merek teh celup sariwangi yaitu 0.443 . Standar deviasi terendah terdapat pada merek teh celup tongtji yaitu 0.025 dan standar deviasi tertinggi pada merek teh celup sariwangi yaitu 0.067 


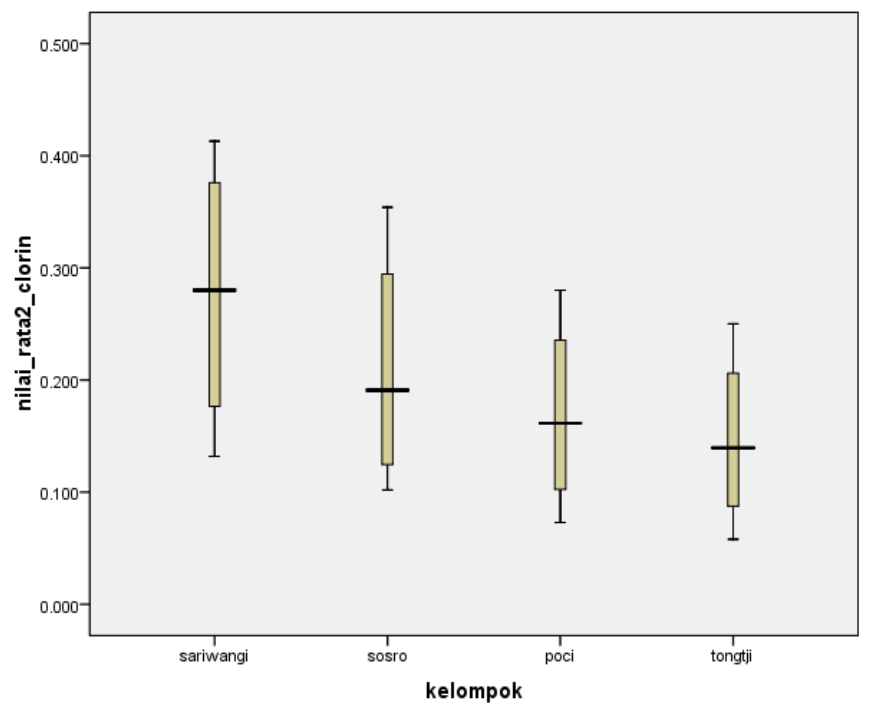

\section{Grafik 1. Box Plot Pada Jenis Teh Celup Merek Berbeda}

Pada boxplot di atas terlihat bahwa data pada jenis merek teh celup berdistribusi normal yakni nilai $p$ lebih besar dari nilai taraf statistic yaitu 0.05 . Data normal ditunjukan oleh uji Shapiro-Wilk pada taraf 0.05 pada merek teh sariwangi 0.862 sosro 0.739 poci 0.951 dan tongji 0.954. Karena berdistribusi normal maka uji statistic yang digunakan adalah uji varians atau Anova dapat dilihat pada tabel berikut ini.

Tabel 3. Uji ANOVA Untuk Kadar Klorin Pada Berbagai Teh Celup dari Berbagai Lama Waktu Seduhan.

\begin{tabular}{|c|c|c|}
\hline Merek Teh & $F$ & Sig. \\
\hline Sariwangi & 16,683 & ,001* \\
\hline Sosro & 37,814 &, $000^{*}$ \\
\hline Poci & 28,650 &, $000^{*}$ \\
\hline Tongtji & 30,005 & ,000* \\
\hline
\end{tabular}

Hasil uji Anova pada berbagai merek teh celup dengan waktu yang berbeda yakni 2 menit, 4 menit, 6 menit dan 8 menit menunjukkan terdapat perbedaan bermakna dimana nilai $\mathrm{p}$ lebih kecil daripada taraf statistic 0,05. Terdapat perbedaan bermakna pada berbagai merek teh celup dan lama waktu seduhan maka dilanjutkan dengan uji lanjut menggunakan uji Tukey dapat dilihat pada tabel 4 berikut. 
Tabel 4. Signifikansi Dari Uji Tukey Untuk Kadar Klorin Pada Berbagai Teh Celup Berdasarkan Lama Waktu Seduhan.

\begin{tabular}{|c|c|c|c|}
\hline Dependent Variable & $\begin{array}{c}\text { Kelompok } \\
\text { (I) }\end{array}$ & $\begin{array}{c}\text { Kelompok } \\
\text { (J) }\end{array}$ & Sig. \\
\hline \multirow[t]{2}{*}{ sariwangi } & 2 menit & $\begin{array}{l}6 \text { menit } \\
8 \text { menit }\end{array}$ & $\begin{array}{l}.006^{*} \\
.001^{*}\end{array}$ \\
\hline & 4 menit & 8 menit & $.009^{*}$ \\
\hline \multirow{4}{*}{ sosro } & 2 menit & 6 menit & $.004^{*}$ \\
\hline & 4 menit & 6 menit & $.034^{*}$ \\
\hline & & 8 menit & $.000^{*}$ \\
\hline & 6 menit & 8 menit & $.007^{*}$ \\
\hline \multirow{4}{*}{ poci } & & 6 menit & $.007^{*}$ \\
\hline & & 8 menit & $.000^{*}$ \\
\hline & 4 menit & 8 menit & $.002^{*}$ \\
\hline & 6 menit & 8 menit & $.036^{*}$ \\
\hline \multirow{4}{*}{ tongtji } & & 6 menit & $.005^{\star}$ \\
\hline & & 8 menit & $.000^{*}$ \\
\hline & 4 menit & 8 menit & $.001^{*}$ \\
\hline & 6 menit & 8 menit & $.012^{*}$ \\
\hline
\end{tabular}

Taraf 0,05 atau $5 \%$

Ket: *: terdapat perbedaan bermakna

Berdasarkan tabel 4 di atas uji statistik dengan menggunakan uji Tukey pada taraf 0,05 terlihat bahwa pada perbandingan antara berbagai merek teh celup yaitu merek teh sariwangi, sosro, poci dan tongtji dengan lama waktu seduhan yang bervariasi yaitu 2 menit, 4 menit, 6 menit, dan 8 menit pada kelompok (i) dengan kelompok (j) ternyata terdapat perbedaan bermakna pada kadar klorin dimana nilai p lebih kecil dari nilai taraf statistic 0,05 untuk lebih jelas dapat dilihat pada lampiran 5 uji Tukey.

\section{Pembahasan}

Hasil penelitian menunjukkan bahwa lamanya waktu seduhan pada teh celup pada perlakuan lama waktu seduhan 2 menit, 4 menit, 6 menit dan 8 menit, berpengaruh terhadap kadar klorin pada teh celup. Berdasarkan uji anova, perlakuan lama waktu seduhan berpengaruh terhadap kadar klorin dimana nilai $p$ yaitu 0.001 , $0.000,0.000$ dan 0.000 lebih kecil dari pada taraf statistik 0,05. Hasil uji dilanjutkan dengan uji Tukey 0,05 menunjukkan terdapat perbedaan yang sangat bermakna pada perbandingan antara lama waktu seduhan 2 menit dengan 8 menit. Hal ini 
menunjukkan bahwa kadar klorin tertinggi diperoleh pada lama waktu seduhan 8 menit pada merek teh celup sariwangi 0,413 ppm. Sedangkan kadar klorin terendah diperoleh pada lama waktu seduhan 2 menit pada merek teh celup yaitu tong tji $0,058 \mathrm{ppm}$.

Data tersebut menunjukkan bahwa semakin lama waktu seduhan, maka kadar klorin akan semakin tinggi. $\mathrm{Hal}$ ini disebabkan semakin lama waktu seduhan maka semakin banyak klorin yang larut dalam air. Sesuai pernyataan yang dikemukakan oleh Suyitno, dkk (1989) bahwa salah satu faktor yang mempengaruhi kelarutan suatu zat adalah waktu, dimana semakin lama waktu kontak maka semakin banyak zat yang dapat larut dalam air. Hal ini didukung pula oleh sifat klorin yang dapat larut dalam air dan bereaksi (Cotton dan Wilkinson, 1989). Menurut Keenan (1989), reaksi antara klorin dengan air adalah sebagai berikut:

$$
\mathrm{Cl}+\mathrm{HOH} \longrightarrow \mathrm{HCl}+\mathrm{OH}
$$

Sedangkan perlakuan jenis teh dan interaksi antara lama waktu seduhan dan jenis teh, berdasarkan uji anova menunjukkan terdapat pengaruh yang artinya bahwa perlakuan jenis teh dan interaksi antara lama waktu seduhan dan jenis teh berpengaruh terhadap kadar klorin. Hasil uji Tukey pada taraf 0,05 menunjukkan bahwa pada merek teh sariwangi, sosro, poci dan tongtji dengan perbandingan lama waktu seduhan 2 menit dengan 6 menit, 2 menit dengan 8 menit, dan 4 menit dengan 8 menit berpengaruh pada kadar klorin. Sedangkan untuk merek teh sosro, poci dan tong tji perbandingan lama waktu seduhan 6 menit dengan 8 menit berpengaruh pada kadar klorin kecuali untuk merek teh sariwangi tidak berpengaruh pada kadar klorin. Dan hanya untuk merek teh sosro perbandingan lama waktu seduhan 4 menit dengan 6 menit berpengaruh pada kadar klorin. Menurut Setiorini, dkk (2010), hal ini diduga karena perbedaan kualitas kertas yang digunakan pada kantong teh celup untuk setiap merek teh celup berbeda sehingga jika teh celup tersebut diseduh ke dalam air maka jumlah kadar klorinnya akan berbeda pula.

Hasil ini sejalan dengan penelitian terdahulu oleh Suryaningrum, dkk (2007), menunjukkan bahwa pada merek teh celup hitam dan teh celup hijau pada lama waktu seduhan 2 menit, 4 menit, 6 menit dan 8 menit terdapat perbedaan kadar klorin pada penelitian terdahulu dengan hasil yang didapat pada penelitian ini. Hasil pada penelitian terdahulu rata-rata kadar klorin pada teh celup hitam $0,041 \mathrm{ppm}$ dan teh celup hijau 0,046 ppm. Tetapi pada penelitian ini terjadi peningkatan kadar klorin dari penelitian terdahulu yang disebabkan oleh banyaknya zat klorin yang terlarut dalam air (Suyitno, 1989).

Pada penelitian ini dimana perlakuan jenis teh dan interaksi antara lama waktu seduhan dan jenis teh berdasarkan uji anova dan uji tukey berpengaruh terhadap kadar klorin. Penelitian ini sejalan dengan penelitian terdahulu oleh Setorini, $d k k$ (2010) pada berbagai merek teh celup hitam dengan lama waktu seduhan yang bervariasi menunjukkan terdapat perbedaan terhadap kadar klorin yang diduga karena perbedaan kualitas kertas pada kantong teh celup yang digunakan.

Menurut World Health Organization (WHO) dalam Suryaningrum, dkk (2007), nilai ambang batas residu klorin dalam air adalah 0,5 ppm. Klorin yang dihasilkan penelitian pada teh celup adalah berkisar antara 0,058-0,413 ppm. Data tersebut menunjukkan bahwa air hasil seduhan pada teh celup mengandung klorin yang aman untuk dikonsumsi manusia. Akan tetapi perlu diwaspadai akumulasi kronik dalam tubuh karena klorin dapat menimbulkan efek bagi kesehatan. Dampak dari teh celup yang mengandung klorin itu tidak terjadi sekarang. Dampak untuk kesehatan baru akan muncul 15 hingga 20 tahun mendatang, khususnya bila kita mengonsumsi teh celup dengan lama waktu seduhan yang salah secara terus menerus. Gangguan kesehatan yang dapat ditimbulkan akibat mengonsumsi teh celup yang mengandung klorin dalam jangka panjang menyebabkan penyakit pada paruparu seperti pneumonitis, sesak nafas, emphisema dan bronkitis (Tirthawidhi, 2011). Disisi lain hasil penelitian terdapat hasil uji hipotesis dimana "terdapat perbedaan kadar klorin pada teh celup yang berbeda berdasarkan waktu seduhan yang berbeda". Hal ini berarti hipotesis kerja $\left(\mathrm{H}_{1}\right)$ diterima dan hipotesis nol $\left(\mathrm{H}_{0}\right)$ ditolak karena berdasarkan uji anova nilai $\mathrm{F}$ hitung lebih 
besar dibandingkan dengan nilai $\mathrm{F}$ tabel (16.683, 37.814, 23.650, 30.005>3.84).

\section{KESIMPULAN}

Berdasarkan hasil penelitian kadar klorin pada teh celup, maka diperoleh kesimpulan bahwa terdapat perbedaan kadar klorin pada berbagai merek teh celup yaitu teh celup sariwangi, teh celup sosro, teh celup poci dan teh celup tong tji berdasakan lama waktu seduhan 2 menit, 4 menit, 6 menit dan 8 menit. Hal ini dapat dilihat dari data yang didapat menunjukkan bahwa kadar klorin tertinggi diperoleh pada lama waktu seduhan 8 menit pada merek teh celup sariwangi 0,413 ppm. Sedangkan kadar klorin terendah diperoleh pada lama waktu seduhan 2 menit pada merek teh celup yaitu tong tii 0,058 ppm.

\section{DAFTAR PUSTAKA}

Adiwisastra, A. 1989. Sumber, Bahaya serta Penanggulangan Keracunan. Penerbit Angkasa Bandung.

Ambar, Roy. 2012. 2 Kandungan Teh Hijau Yang Bermanfaat Untuk Tubuh.

Bambang. 2010. Pengetahuan Dasar Teh. Teh Dan Penggunaannya.

Cotton, F.A dan Wilkinson, Georffrey. 1989. Kimia Organik Dasar. Jakarta: UI Press.

Dewantoro, Anton. 2009. I Sleep with My Eyes Open. Teh (Kandungan teh, manfaat teh, jenis teh, dan karakteristiknya, kekurangan anjuran minum teh).

Diablo. 2008. Agriculture. Morfologi Tanaman Teh.

Fulder, S. 2004. Khasiat Teh Hijau. Prestasi Pustaka Publisher. Jakarta.

Karinda. 2012. Teh Dan Segala Manfaatnya. Keenan, C. W. 1989. Ilmu Kimia Untuk Universitas. Jakarta: Erlangga.

MacDougall, J. A. 1994. Ekspose Pencemaran Di Sumut. Ekspose Singkat Kasus Pencemaran Di Sumatera Utara.

Marthadison, Trisatya. 2012. Khasiat Teh Secara Lengkap.

Muawiah, Abu. 2009. Pemuda Dalam Islam. Ternyata Teh Celup Berbahaya.

Prasetyo. 2003. Analisis Kadar Zat Klorin Pada Air Seduhan Teh Hitam Celup Bermerek Yang Beredar Di Wilayah
Kota Denpasar. Universitas Udayana. Jimbaran.

Pattigrew, Jane. 2002. A Social History of Tea. Teh (Sejarah Teh dan Asal Mula Teh).

PT. Sinar Sosro. 2008. Tanaman Teh.

PT. Sinar Sosro. 2013. Sejarah Sinar Sosro.

PT. Sumisho E-commercee Indonesia. 2014. Teh Celup Sosro.

PT. Sumisho E-commercee Indonesia. 2014. Teh Celup Poci.

PT. Teh Dua Burung. 2013. Teh Celup Tong Tji.

Rahmawati, Yusna. 2012. Teh Hitam dan Komponen Kimia Daun Teh.

Sari, D. Y. 2003. Kompas Kesehatan. Teh Celup Pemicu Kanker.

Semeru, Ashari. 1995. Hortikultural: Aspek Budidaya. Jakarta: UI Press.

Setiorini, Santi, dkk. 2010. Analisa Kadar Klorin Pada Kantong Teh Celup serta Pengaruhnya Terhadap Mutu Teh. Prodi Kesehatan Lingkungan Madiun Jurusan Kesehatan Lingkungan Politeknik Kesehatan, Depertemen Kesehatan Surabaya.

Setiawan, Yohanes. 2013. Sariwangi Teh Asli. Teh Celup Sariwangi.

Sinuhaji, Dian Novita. 2009. Perbedaan Kandungan Klorin (Cl) Pada Beras Sebelum dan Sesudah Dimasak Tahun 2009. Fakultas Kesehatan Masyarakat, Universitas Sumatera Utara.

Sulirawati, Das. 2010. Belajar Kimia Menarik SMA/MA Kelas X.

Suryaningrum, Riana Dyah, dkk. 2007. Peningkatan Kadar Tanin dan Penurunan Kadar Klorin. Jurusan Pendidikan Biologi, FKIP, Universitas Malang.

Suyitno. 1989. Petunjuk Laboratorium Rekayasa Pangan. Yogyakarta: Pau Pangan dan Gizi UGM.

Tirthawidhi, Bayu. 2011. Fakta Tentang Klorin.

U.S. Department Of Health and Human Service. 2007. Chlorine.

Walidaini, Birrul. 2012. Karya IImiah Mahasiswa Universitas Padang. Bahaya Teh Celup. Universitas Negeri Padang.

Wibowo, Trimanto. 2009. Pengaruh Pemberian Seduhan Kelopak Rosela (Hibiscus sabdariffa) Terhadap Kadar Trigliserida darah Tikus Putih (Rattus 
Biopendix, Volume 1, Nomor 1, Oktober 2014, hlm. 22-31

norvegicus). Fakultas Kedokteran Universitas Sebelas Maret, Surakarta.

Widiansyah, Oktafian. 2008. Mengenal Jenis-Jenis Teh.

Wrasiati, Lhu Putu. 2009. Studi Aktivitas Antioksidan Bubuk dan Seduhan Teh
Hijau (Camelia sinensis) yang beredar Di Kota Denpasar. Jurusan Teknologi Industri Pertanian.

Yudana dan Luize. 1998. Intisari Indomedia. Mengenal Ragam dan Manfaat Teh. 